\title{
Climate impacts on reproductive performance of Romanov sheep in the moderate climate
}

\author{
Dražen Đuričića $^{d *}$ (iD | Attila Dobos ${ }^{b}$ Jozo Grbavac ${ }^{\complement}$ Charlotte Stiles ${ }^{d}$ Iva Bacan | Željko Vidas ${ }^{\circledR}$ | \\ Franjo Marković | Predrag Kočila | Marko Samardžija
}

aMount-trade d.o.o., Garešnica, Croatia.

CEVA-PhylaxiaCo. Ltd., Budapest, Hungary.

Faculty of Agriculture and Food Technology, University of Mostar, Mostar, Bosnia and Herzegovina.

Faculty of Veterinary Medicine, University of Zagreb, Zagreb, Croatia.

Faculty of Medicine, Josip Juraj Strossmayer University of Osijek, Osijek, Croatia.

Belupo d.d. Danica, Koprivnica, Croatia.

TSH Čakovec, Čakovec, Croatia.

Corresponding author: dduricic19@gmail.com

\begin{abstract}
This study aimed to investigate the climatological impacts of air temperature, sunshine duration, and rain precipitation, in a moderate climate, on the reproductive performance of Romanov sheep in the continental part of Croatia, during two consecutive years (2019-2020). Our study included 549 matings with 520 successful conceptions at 5 Romanov sheep farms, and the fertility rate was $94.72 \%$. The percentage of lambs delivered in winter was $53.27 \%(n=277)$, in spring $20.19 \%(n=105)$, in summer $14.23 \%(n=74)$ and $12.31 \%$ in autumn $(n=64)$. According to percentile ranks and classification ratings, thermal conditions have been described as very warm (during 2019-2020), while precipitation conditions, expressed in percentiles, were wet (during 2019) but dry (during 2020) for this region. The peak of sexual activity was from mid-August until October in 2019 and from the end of August to November in 2020 for Romanov sheep in northwestern (NW) Croatia. A Kruskal-Wallis test showed a statistically significant difference in the number of pregnant ewes during the different mating seasons in the year $(p<0.001)$. Therefore, we can assume that air temperature, precipitation volume, and sunshine duration during the different seasons could impact the reproductive performance of Romanov sheep in a moderate climate.
\end{abstract}

Keywords: air temperature, rainfall precipitation, reproduction, small ruminant, sunlight

\section{Introduction}

Most European breeds of sheep are seasonal breeders in the moderate climate region; however, the Romanov breed is aseasonally polyoestrous (Đuričić et al 2019). Despite being aseasonally polyoestrous, the distribution of mating and lambing was not uniform through the year for the Romanov breed (Sušić et al 2005; Đuričić et al 2019) in Croatia. During the night, the pituitary gland releases melatonin, which stimulates the hypothalamus-hypophysisovarium axis (Karsch et al 1984; Chemineau et al 1992; Malpaux et al 1996; Rosa and Bryant 2003). The natural breeding season of the seasonally polyoestrous sheep and goat breeds in the Northern Hemisphere is usually restricted between late August and ends in late December with a particular anoestrous period from February to the end of May (Chemineau et al 1992; Rosa and Bryant 2003). Climate and weather have a significant direct effect on the growth and production of livestock (Silanikove 2000). The meteorological variables that are commonly measured (air temperature, humidity, solar radiation, wind, precipitation, among others) could be environmental stressors providing adverse effects on animal welfare and productivity (Marai et al 2007; Bernabucci et al 2010; Santolaria et al 2014; Palacios and
Abecia 2015; Abecia et al 2016; Nejad and Sung 2017). The modulating factors of reproduction in sheep are environmental factors, nutritional status, social interactions, lambing date, and lactation period (Boland et al 2001; Rosa and Bryant 2003). The continental climate is dominant in Croatia's northwestern (NW) part, classified as Cfa climate (based on the Köppen Climate Classification). The Cfa climate is characterised by cold winters and warm summers. Any product of the condensation of atmospheric water vapour that falls under gravity from clouds is precipitation (rain, sleet, snow, ice pellets, among others). The mean annual precipitation of $870 \mathrm{~mm}$ per year classified Croatia as a moderate wet region. Sunlight or sunshine duration (hours) is a climatological indicator of cloudiness, measuring the duration of sunshine in a given period (usually, a day or a year) for a particular location. In the NW part of Croatia, the maximal insolation is $2000 \mathrm{~h}$ per year (Zaninovic et al 2008).

This study aimed to investigate the climatical impacts of air temperature, sunlight duration, and rain precipitation, in a moderate climate, on the reproductive performance of Romanov sheep in the continental part of Croatia, during two consecutive years (2019-2020). 


\section{Materials and Methods}

\subsection{Animals}

The animals were kept in a fenced pasture (rotating pasture), with access to stables during the night. The sheep were naturally mated. Animals had free access to good quality meadow hay, adequate concentrate, and drinking water. During two consecutive years (December 2018 to November 2020), the reproductive performance data of all five Romanov sheep flocks (41-87) in NW Croatia was collected.

\subsection{Ethical approval}

All procedures performed in the studies involving animals followed the institution's ethical standards or practice at which the studies were conducted. The research protocol and animal management were following the Directive 2010/63/EU (European Union 2010) on the protection of Animals used for Scientific Purposes.

\subsection{Meteorological data}

Air temperature, sunshine duration, and daily precipitation volumes were obtained by the Croatian Meteorological and Hydrological Service (CMHS), Zagreb, Croatia, from the nearest meteorological recording station, located within $0.5-25 \mathrm{~km}$ from all farms. Climatological conditions on a monthly or seasonal scale at the meteorological station assessed mean daily variations concerning the corresponding multi-annual average of the climatological reference period 1949-2019.

\subsection{Seasons}

The Winter season refers to January and February of the chosen year and December of the previous year, spring (March to May), summer (June to August), and autumn (September to November).

\subsection{Statistical analysis}

All data were analysed by Stara 13.1 (Stara Corp. USA) using the non-parametric Kruskall-Wallis test. The regression analysis used the percentage of the logarithmic values of pregnant sheep working normalisation of the pregnant sheep distribution. Regression statistics showed a linear association between the percentage of pregnant sheep and the season as variables.

\section{Results}

There were 549 matings with 520 successful conceptions, i.e., lambings at 5 Romanov sheep farms, during two consecutive years (2019-2020). The fertility was $94.72 \%$. The seasonal distribution of lambings (Figure 1): $53.27 \%$ of ewes delivered in winter $(n=277), 20.19 \%$ in spring $(n=105)$, $14.23 \%$ in summer $(n=74)$ and $12.31 \%$ in autumn $(n=64)$.

An analysis of the rainfall precipitation (Figure 1), air temperature (Figure 2), and sunlight hours (Figure 3) variations during years 2019-2020 in NW Croatia to the corresponding multi-annual average of the climatological reference period 1949-2019 are presented in the Figures 1-3.

According to percentile ranks and classification ratings, thermal conditions have been described as very warm (during 2019-2020), while precipitation conditions, expressed in percentiles, were wet (during 2019) but dry (during 2020) for this region (Table 1 ).



Figure 1 Monthly rainfall precipitation $(\mathrm{mm}$ ) variations during the years 2019-2020 in northwestern Croatia to the corresponding multiannual average of the climatological reference period 1949-2019.

The reproductive parameters are presented in Table 2 for Romanov sheep during two consecutive years (20192020) in NW Croatia. There was a statistically significant difference in the number of pregnant ewes between the different mating seasons (Table 3).

A Kruskal-Wallis test showed a statistically significant difference in the number of pregnant ewes between the 
different seasons of mating $(P<0.001)$. The peak of sexual activity was from mid-August until October in 2019 and from the end of August to November in 2020 for Romanov sheep in NW Croatia (Figure 4).

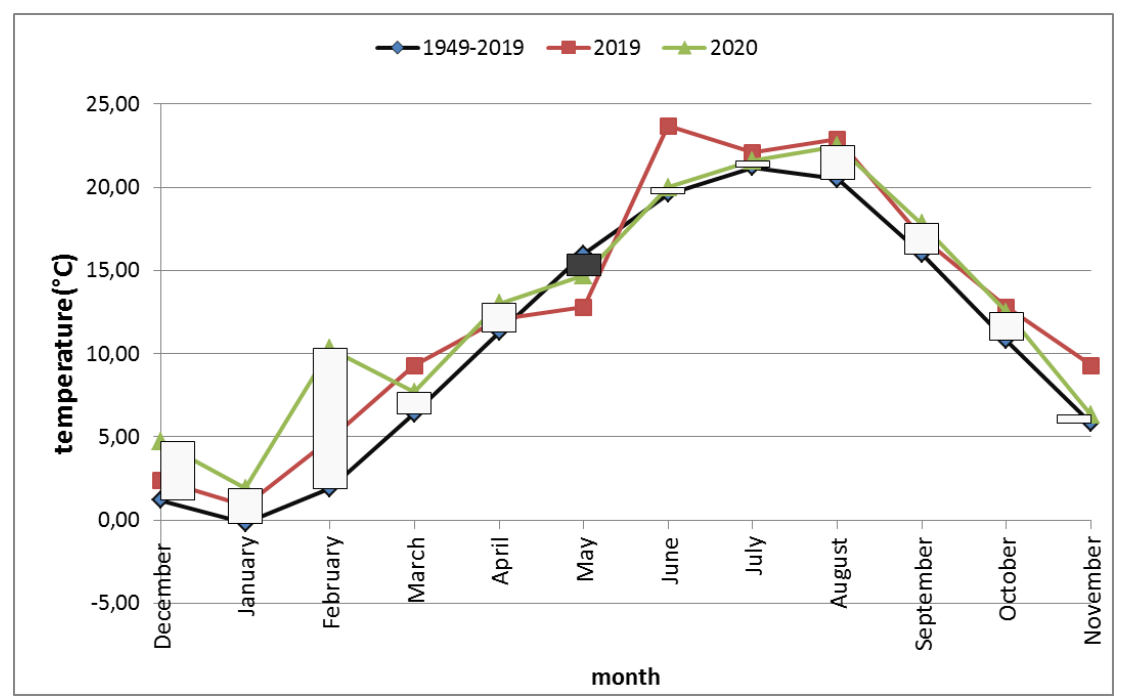

Figure 2 Monthly air temperature $\left({ }^{\circ} \mathrm{C}\right)$ variations during years $2019-2020$ in NWCroatia to the corresponding multi-annual average of the reference climatological period 1949-2019.

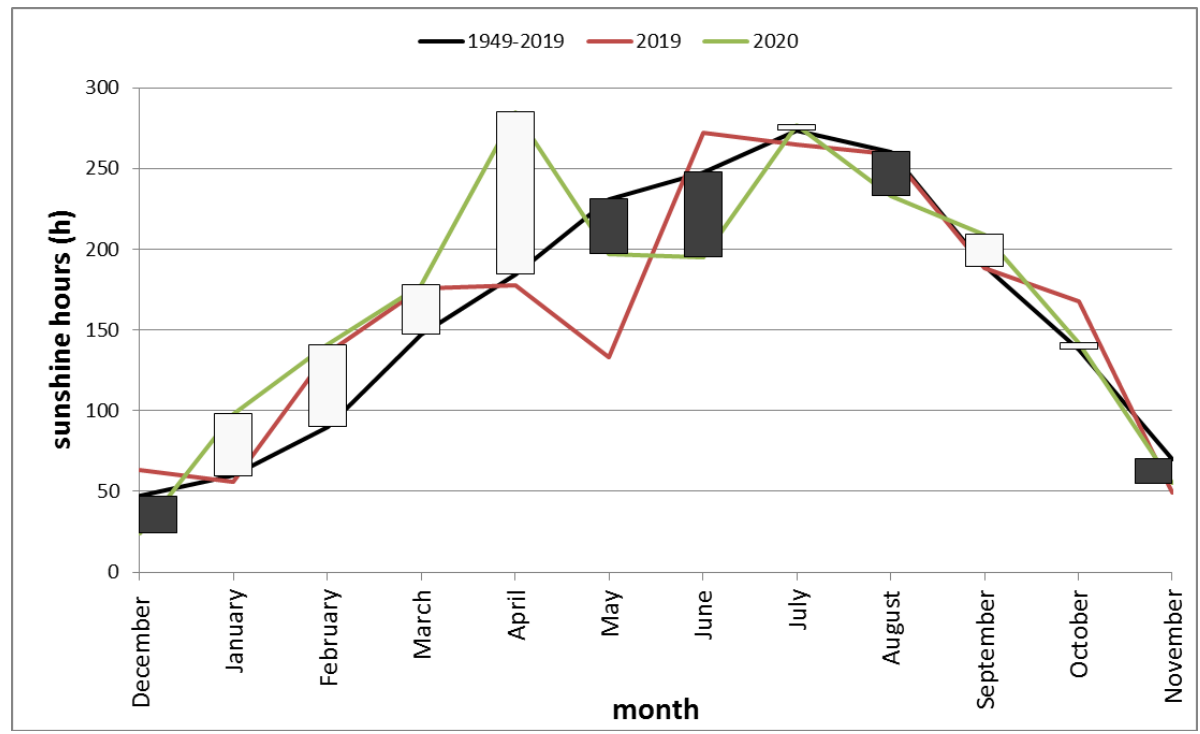

Figure 3 Monthly sunshine hours (h) variations during years 2019-2020 in NW Croatia to the corresponding multi-annual average of the climatological reference period 1949-2019.

\section{Discussion}

Although Romanov sheep are aseasonally polyoestrous, equal seasonal distribution of lambing through the year was not present. It is clear that if lambs are weaned in early spring or midsummer (the anoestrus period for most European sheep and goat breeds) (Đuričić et al 2019), Romanov ewes were "saved "for the breeding season (August to November) to mate, similar to Boer goats (Đuričić et al 2012.). The thermal conditions in NW Croatia have been described as extremely warm and very warm, especially during summer and autumn in 2019 , when more than $10 \%$ of mated ewes were not pregnant. One of the causes of low conception rate could be high air temperatures that can induce embryonic losses and foetal deaths during gestation
(Marai et al 2008; van Wettere et al 2021). Despite extremely warm and very warm seasons during the period of the lowest sexual activity, complete anoestrus did not occur in the Romanov breed, similar to Đuričić et al (2019). Croatia's highest daily average temperatures are in the summer (Cfa climate is characterised by warm summers). The beginning of autumn marks the start of the breeding season, and the air temperatures drop. In addition to the temperature, other factors, such as relative humidity and precipitation, may directly or indirectly affect livestock production and impact periods of reduced oestrous activity (Galina et al 1996). The indirect effect of increased rainfall is mostly through forage availability, resulting in satisfactory fertility results (Forcada 
et al 1992; Abecia et al 2016). In our study, the animals were kept in a fenced pasture but also received supplementation (hay and concentrate), so they were not only dependent on the pasture. The direct negative impact of rainfall was a lower survival rate of newborn lambs during extremely wet autumns in Croatia than during dry autumns (Đuričić et al 2019). In our study, such a negative impact was not present because newborn lambs were kept in shelters with their mothers. In tropical regions, the breeding season is independent of the photoperiod starting during the wet or rainy season, when the air temperatures are lower, with consequent cycles (dry and rainy seasons) in food availability (Vivien-Roels and Pévet 1983).

Table 1 Thermal and precipitation conditions through the seasons in years 2019-2020, and percentage of non-pregnant ewes.

\begin{tabular}{|l|l|c|c|c|c|}
\hline \multirow{2}{*}{ Year } & \multirow{2}{*}{ Parameter } & \multicolumn{4}{|c|}{ Season } \\
\cline { 3 - 6 } & & spring & summer & autumn & winter \\
\hline \multirow{3}{*}{2019} & Temperature & normal & extremly warm & very warm & normal \\
\cline { 2 - 6 } & Rainfall & very wet & very dry & normal & dry \\
\cline { 2 - 6 } & $\%$ non-pregnant & 6.56 & $10.64^{*}$ & $\mathbf{9 . 3 8 ^ { * }}$ & 4.32 \\
\hline \multirow{3}{*}{2020} & Temperature & normal & normal & warm & very warm \\
\cline { 2 - 6 } & Rainfall & very dry & wet & wet & normal \\
\cline { 2 - 6 } & $\%$ non-pregnant & 7.69 & 3.03 & 2.78 & 3.36 \\
\hline
\end{tabular}

Table 2 Reproductive parameters of Romanov sheep $(n=549)$ in NW Croatia during two consecutive years (2019-2020).

\begin{tabular}{lccc}
\hline \multirow{2}{*}{ Reproductive parameters } & \multicolumn{2}{c}{ Years } & Total \\
\cline { 2 - 4 } number of matings & 2019 & 2020 & 549 \\
\hline number of pregnant ewes & 279 & 259 & 520 \\
\hline number of non-pregnant ewes & 261 & 11 & 29 \\
\hline litter size & 18 & 1.65 & 1.59 \\
\hline lambing index & 1.53 & 1.38 & 2.34 \\
\hline lambs/ewe/year & 1.30 & 2.28 \\
\hline total lambs/ewe/lambing & 1.99 & 427 & 826 \\
\hline total lambs/ewe/year & 399 & 589 & 95.93 \\
\hline fertility (\%) & 519 & 93.55 & 94.72 \\
\hline
\end{tabular}

After the autumnal equinox (the first day of autumn), the day begins to shorten, and night begins to become longer until the winter solstice (the first day of winter), giving rise to the shortest day and the longest night of the year. Melatonin is only released at night, so melatonin secretion increases from autumn to early winter in the northern hemisphere. Amongst other mechanisms, melatonin secretion regulates the activity of the hypothalamic-hypophysial-gonadal axis (Karsch et al 1988; Rosa and Bryant 2003), which is crucial as a reproductive strategy for short-day breeder species, sheep and goats. In addition, the most prolonged day hours per month are in summer (monthly average June-August over 250 hours), but towards the end of autumn (in November and December), they are shortened to $50 \mathrm{~h}$ per month. This is a consequence of the day shortening and high cloudiness, beyond the less sunlight (Figure 4 -yellow line).

Table 3 Number of pregnant Romanov ewes during two consecutive years (2019-2020) according to the season of matings.

\begin{tabular}{|c|c|c|}
\hline \multirow{2}{*}{ Season of matings } & \multicolumn{2}{|c|}{ Pregnant } \\
\hline & Median & Min-Max \\
\hline autumn & 46 & $39-53$ \\
\hline winter & 17 & $12-25$ \\
\hline spring & 10 & $5-24$ \\
\hline summer & 7 & $1-27$ \\
\hline P-value (Kruskall-Wallis) & \multicolumn{2}{|c|}{0.00012} \\
\hline
\end{tabular}


The reproductive performance of the Romanov breed in Canada (Fahmy 1989) was high and generally comparable to that in Russia (Kostylev et al 2018), France (Ricordeau et al 1990), other European countries, and in Croatia according to previous (Đuričić et al. 2019) and our present study. The litter size and lambing index did not significantly differ among the two years of study, but the average number of lambs per ewe was 2 (during 2019), while the following year, it was higher by 0.3 lambs per ewe. Casas et al (2005) concluded that Romanov sheep is a very prolific breed (Fahmy 1989; Herman and Herman 2019); however, their fertility rate was $89-92 \%$, lower than in our study.

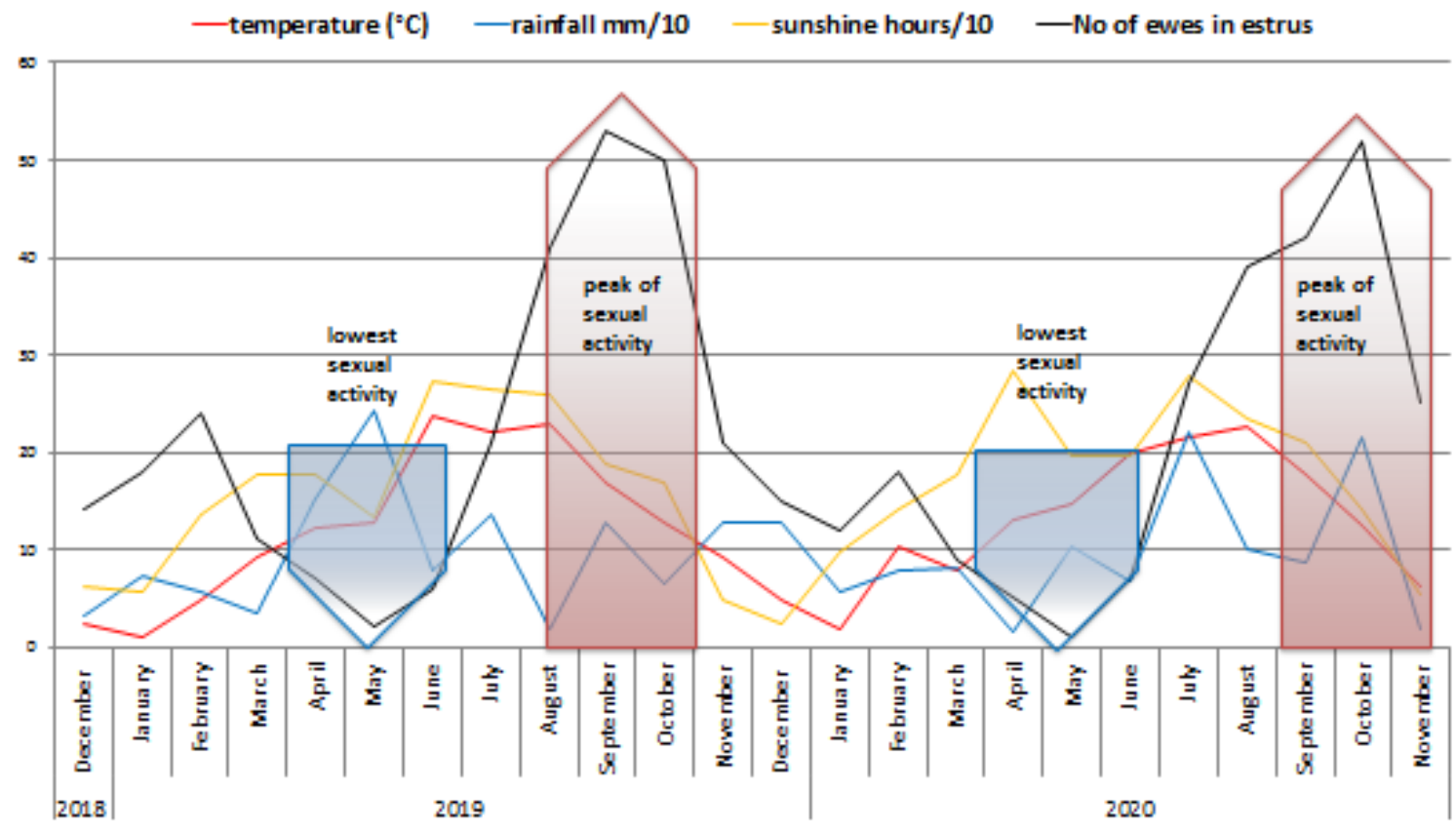

Figure 4 Monthly air temperature, rainfall precipitation, sunshine duration and number of Romanov sheep in heat during 2019-2020, in NW Croatia.

\section{Conclusions}

The seasonal distribution of mating and lambing was not uniform for the Romanov breed in Croatia. The peak of sexual activity was from mid-August until October in 2019 and from the end of August to November in 2020 for Romanov sheep in NW Croatia. According to percentile ranks and classification ratings, thermal conditions have been described as very warm (during 2019-2020), while precipitation conditions, expressed in percentiles, were wet (during 2019) but dry (during 2020) for this region. We can assume that the air temperature, volume of precipitation and sunshine duration during the different seasons could impact the reproductive performance of Romanov sheep in a moderate climate.

\section{Conflict of Interest}

The authors declare that they have no conflict of interest.

\section{Funding}

This research did not receive any financial support.

\section{References}

Abecia JA, Arrébola F, Macías A, Laviña A, González-Casquet O, Benítez F, Palacios C (2016) Temperature and rainfall are related to fertility rate after spring artificial insemination in small ruminants. International Journal of Biometeorology 60:1603-1609. doi: 10.1007/s00484-016-1150-y

Bernabucci U, Lacetera N, Baumgard LH, Rhoads RP, Ronchi B, Nardone A
(2010) Metabolic and hormonal acclimation to heat stress in domesticated ruminants. Animal 4:1167-1183. doi: 10.1017/S175173111000090X

Boland MP, Lonergan P, O'Callaghan D (2001) Effect of nutrition on endocrine parameters, ovarian physiology, and oocyte and embryo development. Theriogenology 55: 1323-1340.

doi: $10.1016 / s 0093-691 x(01) 00485-x$

Casas E, Freking BA, Leymaster KA (2005) Evaluation of Dorset, Finnsheep, Romanov, Texel, and Montadale breeds of sheep: V. Reproduction of F1 ewes in spring mating seasons. Journal of Animal Science 83:2743-2751. doi: $10.2527 / 2005.83122743 x$

Chemineau P, Malpaux B, Delgadillo JA, Guérin Y, Ravault JP, Thimonier J, Pelletier J (1992) Control of sheep andgoats reproduction: use of light and melatonin. Animal Reproduction Science 30: 157-184. doi:10.1016/03784320(92)90010-B

Đuričić D, Grizelj J, Dobranić T, Harapin I, Vince S, Kočila P, Folnožić I, Lipar M, Gregurić Gračner G, Samardžija M (2012) Reproductive performance of Boer goats in a moderate climate zone. Veterinarski arhiv 82: 351-358.

Đuričić D, Benić M, Žura Žaja I, Valpotić H, Samardžija M (2019) Influence of season, rainfall and air temperature on the reproductive efficiency in Romanov sheep in Croatia. International Journal of Biometeorology 63:817824. doi:10.1007/s00484-019-01696-z

Fahmy MH (1989) Reproductive performance, growth and wool production of Romanov sheep in Canada. Small Ruminant Research 2:253-264. doi:10.1016/0921-4488(89)90005-9

Forcada F, Abecia JA, Sierra I (1992) Seasonal changes in oestrous activity and ovulation rate in Rasa Aragonesa ewes maintained at two different body condition levels. Small Ruminant Research 8:313-324. doi:10.1016/09214488(92)90212-M

Galina MA, Morales R, Silva E, Lopez B (1996) Reproductive performance of Pelibuey and Blackbelly sheep under tropical management systems in Mexico. Small Ruminant Research 22:31-37. doi: 10.1016/0921- 


\section{8(95)00878-0}

Herman Yl, Herman Al (2019) Improvement of selection methods of evaluation of the producing composition of the Romanov sheep breed. Animal Breeding and Genetics 57:45-50. doi: 10.31073/abg.57.06

Karsch F, Bittman EL, Foster DJ, Goodman RL, Legan SJ, Robinson JE (1984) Neuroendocrine basis of seasonal reproduction. Recent Progress in Hormone Research 40:185.

Kostylev MN, Abramova MV, Barysheva M (2018) Selection evaluation of productive qualities of breeding sheep of Romanov breed. Agricultural Bulletin of Stavropol Region 3:30-33. doi: 10.31279/2222-9345-2018-7-3130-33

Malpaux B, Viguié C, Skinner DC, Thiéry J, Pelletier J, Chemineau P (1996) Seasonal breeding in sheep: Mechanism of action of melatonin. Animal Reproduction Science 42:107-117. doi:10.1016/0378-4320(96)01505-9

Marai IFM, El-Darawany AA, Fadiel A, Abdel-Hafez MAM (2007) Physiological traits as affected by heat stress in sheep-A review. Small Ruminant Research 71:1-12.

doi: 10.1016/j.smallrumres.2006.10.003

Nejad JG, Sung KI (2017) Behavioral and physiological changes during heat stress in Corriedale ewes exposed to water deprivation. Journal of Animal Science and Technology 59:1-6. doi: 10.1186/s40781-017-0140-x

Palacios C, Abecia JA (2015) Meteorological variables affect fertility rate after intrauterine artificial insemination in sheep in a seasonal dependent manner: a 7-year study. International Journal of Biometeorology 59:585-592. doi:10.1007/s00484-014-0872-y
Ricordeau G, Thimonier J, Poivey JP, Driancourt MA, Hochereau-de-Reviers MT, Tchamitchian L (1990) I.N.R.A. Research on the Romanov sheep breed in France: A review. Livestock Production Science 24:305-332. doi:10.1016/0301-6226(90)90009-U

Rosa HJD, Bryant MJ (2003) Seasonality of reproduction in sheep. Small Ruminant Research 48:155-171. doi:10.1016/S0921-4488(03)00038-5

Santolaria P, Yániz J, Fantova E, Vicente-Fiel S, Palacín I (2014) Climate factors affecting fertility after cervical insemination during the first months of the breeding season in Rasa Aragonesa ewes. International Journal of Biometeorology 58:1651-1655. doi: 10.1007/s00484-013-0770-8

Silanikove N (2000) Effects of heat stress on the welfare of extensively managed domestic ruminants. Livestock Production Science 67:1-18. doi: 10.1016/S0301-6226(00)00162-7

Sušić V, Pavić V, Mioč B, Štoković I, Ekert Kabalin A (2005) Seasonal variations in lamb birth weight and mortality. Veterinarski arhiv 75:375-381.

van Wettere WHEJ, Kind KL, Gatford KL, Swinbourne AM, Leu ST, Hayman PT, Kelly JM, Weaver AC, Kleemann DO, Walker SK (2021) Review of the impact of heat stress on reproductive performance of sheep. Journal of Animal Science and Biotechnology 12:1-18. doi: 10.1186/s40104-02000537-z

Vivien-Roels B, Pévet P (1983) The pineal gland and thesynchronization of reproductive cycles with variations of theenvironmental climatic conditions, with special reference totemperature. Pineal Research Revue 1:91-143.

Zaninovic K, Gajic - Capka M, Percec Tadic M (2008) Climate atlas of Croatia 1961-1990, 1971-2000., Zagreb, Državni hidrometeorološki zavod [in Croatian] 